\title{
Awareness and Practices of Distributed Leadership among Public Elementary School Teachers
}

\author{
Jasmine P. Yulo and Dexter Paul D. Dioso ${ }^{2}$ \\ ${ }^{1}$ Asuncion Ramos Elementary School, Himamaylan City, Philippines \\ ${ }^{2}$ University of Negros Occidental-Recoletos, Bacolod City, Philippines
}

\begin{tabular}{l} 
Article history \\
Submitted: 27 October 2020 \\
Revised: 10 November 2020 \\
Accepted: 12 November 2020 \\
\hline Keywords \\
Education \\
Management \\
Distributed Leadership \\
Awareness \\
Practices \\
Public Elementary School \\
Teachers \\
Descriptive-Correlational \\
Himamaylan City
\end{tabular}

and practices of distributed leadership.
Introduction. The field of school leadership has been continuously increasing in demands and had currently occupied the idea of distributed leadership. Distributed leadership is leadership that is "stretched over leaders and followers, which is beneficial in settings such as schools (Bonneville, 2017). The call for teachers as leaders in school to help implement the K-12 educational system had engaged them to take on collaborative roles. Thus, the study intended to describe the level of awareness and extent of practices of distributed leadership in terms of types such as collaborative, collective, and coordinated as assessed by public elementary school teachers. Moreover, it determined whether a significant relationship existed between the level of awareness and demographic profile, and extent of practices and demographic profile of teachers. Also, it intended to determine if there is a significant relationship between the awareness

Methods. A descriptive-correlational study described the level of awareness and extent of practices of distributed leadership of 73 public elementary school teachers of District 2 of City Schools Division of Himamaylan employed during the school year 2018-2019. Total enumeration of public elementary school teachers were the participants of the study. The data were generated using a modified survey questionnaire adapted from Humphreys (2010) on awareness and practices of distributed leadership. They were analyzed and interpreted using descriptive and inferential statistical analysis with tools such as Mean, Standard Deviation, and Pearson Product Moment of Correlation.

Results. The findings revealed that the public elementary school teachers in District 2 of the City Schools Division of Himamaylan had a very high level of awareness and a very high extent of practices in all three types of distributed leadership namely: collaborative, collective, and coordinated. Furthermore, there is no significant relationship as to the level of awareness and teachers' demographic profile. A significant relationship was found in the extent of practices to demographic profile when the participants were grouped according to educational attainment. The result also showed no significant relationship between the awareness and practices of distributed leadership.

Conclusion. Teachers are a potential asset in teacher leadership roles to enhance the education system, especially in this modern age of education, which requires collaborative, collective, and coordinated effort among the school leaders and teachers. Teaching is also a role of leading. Distributed leadership is advantageous for teachers since it can provide them the opportunity to bring positive change by adopting a more democratic way of classroom and school management. It can immerse teachers in new quality assessment methods that they can use to enhance teaching and learning strategies. The implication for those in formal leadership roles is that they have an important role in creating the conditions for distributed leadership to occur. It is essential to create opportunities for others to lead and build the capacity for improvement in awareness and distributed leadership practice. Faculty development, especially in the areas of acquiring a degree, is a significant opportunity to grow in the practice of distributed leadership. The effect points towards a positive impact of distributed leadership on organizational improvement, leadership capacity building, instructional quality, and school management. Understanding and practicing distributed leadership in school management is the key to the formulation of school-based management policies and the development of interventions supporting the teachers' role in educational organization. 
Practical Value of the Paper. The study may serve as a springboard for leadership skills building and positive change through a distributed leadership training program for teachers. The process involved in the evaluation and improvement of the school leadership utilizing the practice of distributed leadership can promote a collaborative and team-oriented school culture that facilitates effective teaching, empowerment, and development among teachers. The findings of the study may also provide valuable insights for school administrators in implementing programs and leading the school in promoting distributed leadership. Moreover, this study may serve as a guide in conducting further research on distributed leadership practice in leading schools and creating programs that could be helpful in the field of research in education and leadership.

\section{References}

Alegado, P.J.E. (2018). The Challenges of Teacher Leadership in Philippines as experienced and perceived by Teachers. International Journal of Education and Research 6(6), 291-302.

Ali, H.M., \& Yangaiya, S. A. (2015). Investigating the Influence of Distributed Leadership on School Effectiveness: A Mediating Role of Teachers' Commitment. Journal of Educational and Social Research. Volume 5(1 S1), 163.

Bonneville, D. (2017). Demystifying Distributed Leadership: How Understanding Principles of Practice and Perceptions Regarding Ambiguity Can Enhance the Leadership Capacity of Department Chairs. [Doctoral Dissertation. 937, University of Massachusetts Amherst]. Retrieved from https://scholarworks.umass.edu/dissertations_2/937.

Dampson, D.G., Havor, F.M., \& Laryea, P. (2018). Distributed Leadership an Instrument for School Improvement: The Study of Public Senior High Schools in Ghana. Journal of Education and e-Learning Research 5, (2), 79-85. Retrieved from https://doi: 10.20448/journal.509.2018.52.79.85

Erol, Y.C., \& Turhan, M. (2018). The relationship between distributed leadership and family involvement from the parents' perspective. Educational Sciences: Theory \& Practice 18(3), 525-540. Retrieved from http://dx.doi. org/10.12738/estp.2018.3.0088.

Halverson, R., \& Clifford, M. (2013). Distributed instructional leadership in high schools. Journal of School Leadership, 23(2), 389-19. Retrieved from dm.education.wisc.edu/rrhalverson/intellcont/110411 Halverson Clifford-1.pdf

Humphreys, E. (2010). Distributed leadership and its impact on teaching and learning. [Education Doctorate Dissertation, National University of Ireland Maynooth]. Retrieved from www.eprints.maynoothuniversity.ie.

Pasia, A.J. (2019). Educational Leadership Strategies to Facilitate A School Transition into The Philippine K To 12 Basic Education Curriculum. International Journal of Education and Research 7(7).

Yılmaz, D., \& Turan, S. (2015). Distributed leadership view in schools: A structural equation modeling study. Educational Administration: Theory and Practice 21(1), 93-126.

\section{Correspondence:}

Jasmine P. Yulo [jsmnyulo@gmail.com]

http://orcid.org/0000-0002-4908-268X 